\title{
Från komplex romanfigur till stereotypisk hårdkokt hjälte? Lisbeth Salanders transformation i Det som inte dödar oss
}

\author{
Linda Piltz
}

\section{Inledning}

Stieg Larssons (1954-2004) Millennium-trilogi (2005-2007) har under de senaste tio åren blivit ett internationellt populärkulturellt fenomen och romanserien har adapterats till flera andra kvalificerade medier, översatts i femtio länder och sålt i över åttio miljoner exemplar världen över. Trilogin kan således med Kerstin Bergmans (2013b) ord definieras som en hyperbestseller, på samma gång som romanserien synliggör det som Jim Collins (2010) anser utmärka litteraturens villkor i samtiden, nämligen en förskjutning från litterär kultur till populär kultur (Bergman 2013b: 107; Collins 2010: 3ff). Även den komplexa och dynamiska huvudkaraktären Lisbeth Salander har blivit ett internationellt populärkulturellt fenomen som inspirerar, berör, utmanar och provocerar (Söderberg 2013: 52). År 2015 kom den fjärde delen i Millennium-serien, Det som inte dödar oss, skriven av David Lagercrantz. ${ }^{1}$ Även den fjärde romanen har blivit en internationell succé och har i dagsläget sålt i över sex miljoner exemplar i fyrtiosju länder. Det som inte dödar oss har överlag tagits emot mycket väl av både förväntad målgrupp och litteraturkritiker, bland annat eftersom texten uppfattas som respektfull och trogen mot Millennium-trilogin (se exempelvis Svedjedal 2015). Samtidigt som den fjärde romanen i viss mån kan tolkas som respektfull i förhållande till sina litterära förlagor, kan man ställa sig frågan vad som egentligen händer med en komplex och mångfacetterad romanfigur som Lisbeth Salander när en annan författare än den ursprungliga går i dialog med fiktionsvärlden?

I denna artikel är min avsikt att jämföra just detta, nämligen Lisbeth Salanders transformation från Millennium-trilogin till Det som inte dödar oss. För att studera Lisbeth Salanders transformation används en komparativ metod som fokuserar på genretypiska drag, jämte hur kön/genus och aktörskap speglas i relation till narratologiska och tematiska inslag och i karaktärsskildringen överlag. Beträffande disposition är artikeln uppdelad i tre övergripande delar. I första delen avhandlas hur Det som inte dödar oss genremässigt avviker från Millennium-trilogin. I andra delen diskuteras skildringen av Lisbeth Salander i Det som inte dödar oss, samt på vilket sätt framställningen skiljer sig från trilogin. Fokus i denna del kommer att ligga på kön/genus och aktörskap. Avslutningsvis dras möjliga slutsatser utifrån analysen.

\footnotetext{
${ }^{1}$ Under arbetet med denna artikel har även en femte del i Millennium-serien kommit ut, nämligen Mannen som sökte sin skugga (2017). Även denna roman är skriven av David Lagercrantz. År 2019 förväntas också en tredje Millennium-bok av David Lagercrantz komma ut.
} 


\section{Artikelns teoretiska verktygslåda och tidigare forskning}

I artikeln används de teoretiska begreppen performativitet, stabilt kön och filmiserad roman. Med termen performativitet åsyftas Judith Butlers antagande i Gender Trouble (1990), nämligen att kön/genus, sexualitet, begär och identitet görs genom diverse performativa handlingar som upprepas i det kroppsliga och/eller språkliga agerandet och därför materialiserar mening (Butler 2007: xv-xvii). Samtidigt som de performativa handlingarna direkt och indirekt speglar samhälleliga normer, öppnar de också upp för subversiva aktörskap, det vill säga möjligheten att som subjekt i det kroppsliga och språkliga agerandet förändra, ifrågasätta och utmana diverse värde- och makthierarkier (Butler 2007: 107ff). Termen stabilt kön kan kopplas till termen den heterosexuella matrisen som åsyftar Butlers antagande att den heterosexuella, tvåsamma och monogama livsstilen fungerar styrande och normerande, trots att människor gör olika identiteter och sexuella begär (Butler 2007: 208). Butler menar att begreppet betecknar det raster av kulturell begriplighet där kroppar, genus och begär naturaliseras (Butler 2007: 208). Den heterosexuella matrisen utgår från att det endast finns två kön, ett kvinnligt och ett manligt, vilka ses som varandras motpoler samtidigt som de antas begära varandra. Enligt Butler förutsätter den heterosexuella matrisen en begriplig kropp, som uppnås genom ett stabilt kön och som uttrycks genom ett stabilt genus (Butler 2007: 208). En begriplig kvinna förväntas alltså ha en kropp som direkt kan identifieras som en stabil kvinnokropp, på samma gång som kvinnan bör agera enligt föreställningar kopplade till femininitet.

Med termen filmiserad roman avses i sammanhanget Anders Ohlssons definition i "Den filmiserade romanen" (2002), nämligen en litterär text som direkt/öppet eller indirekt/dolt anknyter till filmmediet (Ohlsson 2002: 235ff). Vad det gäller tidigare forskning kring Millennium-trilogin är denna omfattande och bland annat har Lisbeth Salander analyserats utifrån ett genusperspektiv i ett flertal studier (se exempelvis Söderberg 2013; Bränström Öhman 2013; Fahlgren 2013; King \& Lee Smith 2012). Dock är tidigare forskning kring Det som inte dödar oss begränsad, och inga studier är gjorda där huvudfokus ligger på huvudkaraktärens transformation från trilogin till den fjärde romanen.

\section{Millennium-seriens transformation genremässigt}

Enligt Kerstin Bergmans och Sara Kärrholms definition i "Inledning” i Kriminallitteratur (2011), kan alla de fyra romanerna i Millennium-serien kategoriseras inom den övergripande genren kriminallitteratur/deckare då de är fiktiva framställningar där brott och utredningar av brott är centrala i berättelserna (Bergman \& Kärrholm 2011: 11). Förutom att texterna gestaltar brott och utredningar, skriver de också alla explicit i paratexterna in sig i genren genom att på omslagen benämna texterna som kriminalromaner (Lagercrantz 2015; Larsson 2007; Larsson 2006; Larsson 2005). Vidare kan de fyra litterära texterna också kategoriseras inom olika undergenrer, och det är just genretypiska drag kopplade till olika subgenrer som markerar en avgörande skillnad mellan Millennium-trilogin och Det som inte dödar oss; en skillnad som också kan tolkas påverka karaktärsskildringen av Lisbeth Salander.

Om man börjar med Millennium-trilogin kännetecknas denna av att den blandar genretypiska element från en mängd olika deckarsubgenrer. Som exempel kan man nämna att trilogin innehåller inslag från klassiska detektivberättelser då karaktärsskildringen av Lisbeth 
Salander kan tolkas spegla fantastiska inslag eller om man så vill superhjältedrag, i kombination med att berättelserna fokuserar på brotten som logiska problem som går att lösa genom rationellt tänkande (Kärrholm 2011c: 56-58). Likaså innehåller trilogin element och intertexter hämtade från barn- och ungdomsdeckare, pusseldeckare, politisk och psykologisk thriller och hårdkokt deckare (Bergman 2013a: 41-51). Just kopplingen till barn- och ungdomsdeckare skriver Kerstin Bergman (2013a) följande om: ”The repeated references to children's detective stories add a streak of humor and stand in stark contrast to the ghastly and far from child-friendly events of Larsson's novel (the serial killer storyline, the rapes of Harriet and Salander)” (Bergman 2013a: 42). Vidare framhåller Bergman hur huvudkaraktären Mikael Blomkvist vid upprepade tillfällen i trilogin liknas vid Astrid Lindgrens fiktiva pojkdetektiv Kalle Blomkvist (Bergman 2013a: 43). Förutom att trilogin innehåller en rad inslag och intertexter hämtade från undergenrer kopplade till kriminallitteratur, anspelar också romanerna öppet och dolt på flera andra populära genrer; berättelserna är så kallade genrehybrider (Bergman 2013a: 53; Bergman 2013b: 107). Bergman belyser till exempel släktskapet och likheterna mellan Lisbeth Salander och starka kvinnliga hjältar i actionfilmer (Bergman 2013a: 53). Dessutom återfinns fiktiva skildringar av olycklig kärlek och kärleksrelationer i Flickan som lekte med elden (2006) och Luftslottet som sprängdes (2007), motiv som är vanligt förekommande inom den övergripande genren kärleksroman (Öhman 2006: 49ff; för textutdrag i romanerna, se exempelvis Larsson 2006: 564-566; Larsson 2007: 649-650).

Gällande möjliga genrekategoriseringar av Det som inte dödar oss, skiljer sig dessa på många sätt från trilogin. Förenklat kan man säga att den mest avgörande förändringen är att Det som inte dödar oss inte innehåller drag, element och intertexter från en mängd populära genrer utan istället domineras romanen av element hämtade från två subgenrer, nämligen den hårdkokta deckaren och den politiska thrillern. Rörande den hårdkokta deckaren kännetecknas denna av realistiska inslag kopplade till en storstadsmiljö, i kombination med en hårdkokt, alienerad, argsint, pessimistisk, asocial, våldsam och cynisk hjälte; en så kallad outsider som till exempel Lisbeth Salander (Kärrholm 2011b: 88-89; Scaggs 2005: 59-60). Ytterligare ett kännetecken för den osociala hjälten är att hen drivs av ett personligt engagemang och agerar efter sina egna regler (Kärrholm 2011b: 91; Scaggs 2005: 60). Den hårdkokta hjältens personliga infallsvinkel, eller om man så vill den hårdkokte hjältens personliga vendetta, avspeglar sig tydligt i skildringen av Lisbeth Salander då hon i den fjärde romanen endast engagerar sig för att hon vill stoppa sin tvillingsyster Camilla Salander (Lagercrantz 2015: 359ff). Ett annat typiskt drag inom den hårdkokta deckaren, vilket även detta speglas i Det som inte dödar oss, är Femme Fatale-motivet (Kärrholm 2011b: 96, 100101; Brigley Thompson 2013: 136-140). Förutom att Femme Fatale-motivet många gånger sammankopplas med den hårdkokta deckaren, förknippas det också med filmgenrerna retronoir och neo-noir (Brigley Thompson 2013: 136-138). Utmärkande drag för klassiska Femme Fatale-figurer är att de är självständiga, vackra, sexiga, farliga, lömska och förföriska kvinnor som med sina stabila kvinnokroppar och iscensättandet av kvinnlighet och heterosexuellt begär, förleder män och den hårdkokte hjälten på olika sätt; ett kön/genusgörande som får förödande konsekvenser för män överlag och speciellt för den hårdkokte hjälten (Kärrholm 2011b: 96, 100-101; Brigley Thompson 2013: 136ff). I Det som inte dödar oss är intrigen i 
mångt och mycket uppbyggd kring kampen på liv och död mellan den hårdkokte hjälten (Lisbeth Salander) och den farliga Femme Fatale-figuren (Camilla Salander):

PÅ TELEFONEN HADE det stått: Nästa gång, syster, nästa gång! Meddelandet var skickat tre gånger, men om det var ett tekniskt misstag eller en löjlig övertydlighet kunde hon inte avgöra. Det spelade nu ingen roll. Meddelandet var uppenbart från Camilla, men det stod ingenting i det som inte Lisbeth redan förstått. Inget kunde ju vara klarare än att händelserna på Ingarö bara förstärkt och fördjupat det gamla hatet. (Lagercrantz 2015: 477)

Intressant i sammanhanget är att tvillingsystern är allt som Lisbeth Salander inte är och hon beskrivs som änglalik, gudomlig, bedårande, empatisk, smakfull, glad, pratsam, förförisk, vacker, sensuell, mogen och ljuvlig (se exempelvis Lagercrantz 2015: 346, 361, 387). Därtill beskrivs tvillingsystern vid ett flertal gånger som ett oskrivet blad som människor (framför allt stabila män) kan projicera sina fantasier på; ett annat karakteristiskt drag för traditionella Femme Fatale-figurer: ”Alla som sett henne skildrade henne på olika sätt, precis som om de projicerade sina drömbilder av en kvinna på henne” (Lagercrantz 2015: 465). Inte bara framställs den hårdkokte hjälten och den klassiska Femme Fatale-figuren som varandras motsatser, utan tvillingsystern utgör också ett direkt hot mot Lisbeth Salander och samhället överlag; ett samhälleligt hot som kommer att diskuteras utförligare i relation till Lisbeth Salanders transformation i del två av artikeln. Ett annat framträdande drag i den hårdkokte detektivromanen och speciellt i relation till Femme Fatale-motivet är den visuella gestaltningen; en visuell medvetenhet som på olika sätt anspelar på det kvalificerade mediet film (Kärrholm 2011b: 90). Även detta inslag kommer att diskuteras mer ingående i del två.

För att återkoppla till definitionen politisk thriller passar även denna eftersom kampen mot fienden, ett högt tempo, och diverse spänningselement är centrala inslag i berättelsen (Bergman 2011b: 124-125; Scaggs 2005: 105-121). Utöver detta gestaltas vanligt förekommande motiv som den "vanlige” manlige hjälten (i detta fall Mikael Blomkvist) som varken är agent eller professionell spion, och som av olika anledningar blir indragen i storpolitiska spionaffärer (Bergman 2011b: 126-127). Romanen gestaltar även andra populära teman och motiv inom nutida politiska thrillers som till exempel företagsspionage och hur myndigheter och multinationella företag på olika sätt utnyttjar och missbrukar modern informationsteknologi, till exempel genom övervakning (Bergman 2011b: 126). Stor vikt läggs också vid att skildra korrekta facktermer och detaljer gällande teknik och matematiska formler, något som enligt Bergman är ett karakteristiskt drag inom politisk thriller för att skapa en känsla av trovärdighet (Bergman 2011b: 126).

\section{Lisbeth Salanders transformation i Det som inte dödar oss}

Lisbeth Salander gestaltas i Millennium-trilogin genom direkt och indirekt karakterisering, och hon kan tolkas som rund och dynamisk eftersom hon på många sätt är komplex och genomgår en inre och yttre utveckling. Lisbeth Salander har till exempel i trilogin många vitt skilda personlighetsdrag och egenskaper, och hon är allt från känslosam och vemodig kärlekspartner, till konfliktfylld och osocial våldsverkare med superhjältedrag. Som läsare upplever man skildringen av Lisbeth Salander både via extern och intern fokalisering. Tänkvärt i sammanhanget, vilket även Bergman (2014) och Söderberg (2013) poängterar, är att när man som läsare upplever Lisbeth Salander genom en viss karaktärs perspektiv, är 
dessa karaktärer ofta stabila män med stabila genusgöranden utifrån föreställningar kopplade till maskulinitet (Bergman 2014: 95; Söderberg 2013: 57). Dessa manliga karaktärer, med sina manliga blickar, uppfattar ofta Lisbeth Salander som en androgyn, gåtfull/fantastisk, vemodig och utomsocial outsider med någon sorts psykisk variation (se exempelvis Larsson 2005: 40, 224). Det androgyna, det gåtfulla/magiska, det vemodiga och det utomsociala draget hos huvudkaraktären kan i sin tur ses som en dold intertext till Pippi Långstrumpböckerna (1945-1948), då dessa fyra drag enligt Ulla Lundqvist (1994) utmärker just Pippifiguren (Lundqvist 1994: 199).

En annan intressant aspekt i relation till blickarna är att när man som läsare upplever Lisbeth Salander utifrån de manliga karaktärernas perspektiv kan man tolka det som att fokaliseringen har filmiska drag, det vill säga en indirekt narrativ filmisering (Ohlsson 2002: 235, 238-239). De filmiska dragen kan kopplas till det faktum att männens uppfattning av den fiktiva huvudkaraktären bygger på diverse synintryck; nästan som om de ser Lisbeth Salander som en aktör i en film. Likaså imiterar berättandet på olika sätt filmmediets estetik, och till exempel används visuella markörer som bilder, ser, tittar, iakttar och blickar frekvent. Utöver detta zoomar de manliga karaktärerna in den fiktiva verkligheten vid ett flertal gånger som genom en ram eller om man så vill kameralins, det vill säga en filmisk projicering (Ohlsson 2002: 239). Eftersom de manliga karaktärerna ständigt redogör för vad de ser eller iakttar i relation till Lisbeth Salander, kan man uppleva att seendet är centralt och också en viktig aspekt i den direkta och indirekta karakteriseringen av huvudkaraktären. Samtidigt är det så, vilket även Söderberg poängterar, att det finns ett motstånd och ett ifrågasättande av männens blickar i Lisbeth Salanders eget seende, och när man upplever det skildrade genom huvudkaraktärens perspektiv motsäger detta seende männens upplevelse av henne (Söderberg 2013: 61-62). Detta intryck förstärks ytterligare av att huvudkaraktären i trilogin många gånger i det kroppsliga och språkliga agerandet får möjlighet att förändra, ifrågasätta och utmana diverse värde- och makthierarkier, det som Butler benämner som en öppning för subversiva aktörskap (Butler 2007: 107ff). Som läsare av trilogin ges man således genom Lisbeths Salanders performativa handlingar, en möjlighet att se igenom de manliga karaktärernas förenklade beskrivning av henne (Bergman 2014: 95).

En annan möjlighet till att se igenom de manliga karaktärernas ytliga bild av huvudkaraktären är genom de på olika sätt betydelsebärande intertexterna, och som tidigare påtalats anspelar trilogin direkt och indirekt på flera subgenrer kopplade till kriminallitteratur. Inte bara anspelar trilogin på olika deckare och detektivtyper, utan Lisbeth Salander jämförs till exempel vid ett flertal gånger med en feministisk hämnare (en ofta förekommande rollkaraktär i film), en tecknad Tomboy (en vanlig karaktär i Manga- eller animeinspirerade serier) och superhjälten Wasp. ${ }^{2}$ Utöver feministisk hämnare, Tomboy och Wasp, liknas också

\footnotetext{
${ }^{2}$ Superhjälten Wasp, från början kläddesignern Janet van Dyne, är en kvinnlig superhjälte skapad av Stan Lee och Jack Kirby (1917-1994) för det amerikanska serieförlaget Marvel Comics. Wasp är i de tidiga serierna gift med doktor Henry Pym, och hon kallas ofta av sin man och de andra seriefigurerna för ”Den Underbara Wasp” på grund av sitt sexiga, kvinnligt kodade yttre. Wasp superkrafter är att hon kan växla i storlek (stor/liten), har getingvingar, och att hon kan ge kraftfulla elektriska stötar. I likhet med många andra Marvelhjältar har karaktären Wasp vid ett flertal gånger adapterats till TV och film. Som exempel kan man nämna att Hope van Dyne, Janet van Dynes dotter, ikläder sig rollen som Wasp i filmen Ant-Man and the Wasp som har premiär sommaren 2018.
} 
Lisbeth Salander både till det yttre och inre vid upprepade tillfällen med Pippi Långstrump; en liknelse som dock inte huvudkaraktären själv uppskattar:

"Kalle Blomkvist."

"Han avskyr smeknamnet, vilket man kan förstå. Någon skulle få en fläskläpp om jag blev kallad Pippi Långstrump på en löpsedel.”

Hon kastade en mörk blick på Armanskij, som svalde. Han hade vid fler än ett tillfälle tänkt på Lisbeth Salander som just Pippi Långstrump och tackade sitt goda omdöme för att han aldrig försökt skämta om saken. (Larsson 2005: 53)

Den betydelsebärande öppna och dolda dialogen mellan Pippi-gestalten och Lisbeth Salander skriver Bergman (2013a) och Söderberg om. Bergman nämner de explicita intertexterna till Pippi-figuren, och hur både Pippi Långstrump och Lisbeth Salander kan ses som oberoende och självständiga hjältar (Bergman 2013a: 44). Söderberg däremot belyser hur huvudkaraktären i trilogin kan tolkas vara gestaltad utifrån ett slags Pippi-matris (Söderberg 2013: 63). Denna Pippi-matris kan utöver det androgyna, det gåtfulla/fantastiska, det vemodiga och det utomsociala draget, kopplas till bland annat Lisbeths Salanders utseende, bakgrund och livsstil (Söderberg 2013: 57). Söderberg framhåller till exempel Lisbeth Salanders skeva identitetsgörande, hennes brist på social kompetens, hennes Pippi-liknande klädmarkörer, hennes överdrivna makeup och hennes röda hår som hon färgar svart (Söderberg 2013: 57-58). Vidare argumenterar Söderberg för att Lisbeth Salanders obegränsade ekonomiska tillgångar och hennes fysiskt och/eller psykiskt icke fungerande föräldrar kan ses som en dold intertext till Pippi-gestalten (Söderberg 2013: 58-59). Oavsett hur man tolkar de intertextuella referenserna till en feministisk hämnare, Tomboy-figuren, Wasp-gestalten och Pippi-figuren, har de det gemensamt att de kan fungera som ett förklarande tolkningssamband. Likaledes kan de vitt skilda intertexterna, i kombination med Lisbeth Salanders möjlighet till subversivt aktörskap, bidra till att en mer komplex och mångfacetterad bild av huvudkaraktären träder fram. Nämnas bör också att den komplexa karaktärsbeskrivningen i Millennium-trilogin, i sin tur öppnar upp för fler psykologiska och symboliska tolkningsnivåer av huvudkaraktären.

Om man istället ska analysera karaktärsbeskrivningen av Lisbeth Salander i Det som inte dödar oss sker denna främst via direkt karakterisering, även om det också finns viss indirekt karakterisering. Om huvudkaraktären i trilogin kan tolkas som komplex och dynamisk, kan huvudkaraktären i den fjärde romanen snarare tolkas som tämligen platt och statisk. Som exempel kan nämnas att Lisbeth Salander endast tycks ha vissa egenskaper och personlighetsdrag; egenskaper och personlighetsdrag som i sin tur kan kopplas till den hårdkokte, stereotypiske och många gånger manlige hjälten (Kärrholm 2011b: 90-92). Huvudkaraktären beskrivs bland annat som cynisk, livsfarlig, våldsbenägen, ilsken och arg (se exempelvis Lagercrantz 2015: 169, 360, 473). Beträffande Lisbeth Salanders möjlighet till aktörskap, sker detta överlag genom kroppsligt agerande i form av crackning eller våld: "Den unga kvinnan reagerade blixtsnabbt, och slog honom i ansiktet, två, tre gånger som en tränad boxare och fällde honom sedan med en spark mot benen” (Lagercrantz, 2015: 452). Tilläggas bör dock att möjligheten till subversiva aktörskap för huvudkaraktären i den fjärde romanen är begränsad, eftersom Lisbeth Salander i mångt och mycket bara har tagit över manligt kodade aktörskap. Med Butlers terminologi agerar således Lisbeth Salander enligt 
föreställningar kopplade till maskulinitet på samma gång som hennes kropp överlag tycks uppfattas som en stabil kvinnokropp, det vill säga en kropp som omgivningen direkt identifierar som en kvinna (Butler 2007: 208). Denna iscensättning av kön/genus kan säkert av vissa mottagare tolkas som ett subversivt aktörskap; ett subversivt aktörskap som i sin tur kan uppfattas som ett ifrågasättande och en kritik av diverse patriarkala maktdiskurser (Butler 2007: 107ff). Samtidigt kan man ställa sig frågan om inte manligt kodade aktörskap kopplade till stabila kvinnokroppar snarare förstärker och upprätthåller diverse patriarkala maktdiskurser, än ifrågasätter dem (Butler 2007: 208; Kärrholm 2011a: 197-198).

Vad det gäller mediala fenomen kopplade till det kvalificerade mediet film, kan man även i den fjärde romanen finna en mängd filmiska drag, både en narrativ och tematisk filmisering (Ohlsson 2002: 240). Som exempel kan man nämna att det finns explicita och implicita intertexter till filmer, skådespelare och filmkaraktärer, till exempel till noir-filmer och superhjältar. Likaså anspelar berättartekniken på olika sätt på filmmediets estetik, till exempel genom att i gestaltandet av tiden härma filmens växelklippning (Ohlsson 2002: 238). Dessa filmiska inslag och element kan i sin tur göra att man som läsare kan tolka berättelsen som en filmiserad roman (Ohlsson 2002: 235ff). Nämnas i sammanhanget bör dock att de filmiska dragen i den fjärde romanen, på många sätt skiljer sig från de filmiska dragen i trilogin. Visserligen har även den interna fokaliseringen genom de manliga karaktärernas sätt att se i Det som inte dödar oss filmiska drag, men skillnaden är att huvudkaraktären med sina blickar inte i samma utsträckning tillåts att göra motstånd mot männens seende av henne. Den manliga blickens direkta och indirekta karakterisering av Lisbeth Salander får således i mångt och mycket stå oemotsagd. Istället kännetecknas den fjärde romanen bland annat av att gestaltningen av Camilla Salander vädjar till mottagarnas bildseende på olika sätt, till exempel genom ett rikligt bruk av visuella markörer (Ohlsson 2002: 239-240). Likaså beskrivs Camilla Salanders blick ingående vid ett flertal gånger:

Lisbeth har berättat hur Camilla satt i timmar framför spegeln bara för att träna sin blick. Hennes ögon var ett fantastiskt vapen. De kunde både förtrolla och frysa ut - få barn och vuxna att känna sig utvalda och speciella ena dagen och helt förkastade och avvisade nästa. Det var en ond gåva, och som du kan ana blev hon genast otroligt populär i skolan. (Lagercrantz 2015: 362)

Inte bara skildras Camilla Salanders blick som ett vapen, utan hennes seende anspelar också på fotografiska och filmiska grepp som beskärning och in- och utzoomning. Därtill försöker också tvillingsystern på olika sätt iscensätta och regissera den fiktiva verkligheten, vilket enligt Anders Ohlsson (2002) är ett vanligt inslag i filmiserade romaner (Ohlsson 2002: 238).

Ett annat medialt samspel till det kvalificerade mediet film är de tydliga parallellerna till mönstret i film-noir (Kärrholm 2011b: 90; Ohlsson 2002: 240). Som tidigare påtalats beskrivs Lisbeth Salander i den fjärde romanen överlag som en hårdkokt hjälte med en skoningslös och personlig agenda. Denna personliga agenda kan i sin tur kopplas till ett annat noir-inslag, nämligen kampen med och besattheten av Femme Fatale-figuren. Nämnas bör att intrycket av Lisbeth Salander som hårdkokt hjälte med ett manligt kodat aktörskap, ytterligare förstärks av att hon ständigt jämförs med sin kvinnligt kodade tvillingsyster: 
De valde olika sidor i striden skulle man kunna säga. Döttrarna är visserligen tvåäggstvillingar, men har aldrig varit lika, vare sig i utseende eller till sättet. Lisbeth föddes först. Camilla kom tjugo minuter senare, och var tydligen redan som liten en fröjd att titta på. Medan Lisbeth var en ilsken varelse, fick Camilla alla att utbrista ’Å, vilken söt flicka' [...] (Lagercrantz 2015: 360).

Tänkvärt i sammanhanget är också att i kampen mellan den hårdkokte hjälten och Femme Fatale-figuren, kan Lisbeth Salander tolkas som den som försvarar samhället, medan Camilla Salander snarare kan tolkas som ett samhälleligt hot. Om Lisbeth Salander är en upprätthållare av ordning, är Camilla Salander således en samhällsomstörtande kraft som den hårdkokte hjälten måste stoppa. Enligt Zoë Brigley Thompson (2013) och Kerstin Bergman (2011a) är det ett vanligt motiv i noir-filmer (och i hårdkokta detektivromaner) att vackra kvinnliga karaktärer framställs som en fara för män och för samhället överlag (Brigley Thompson 2013: 137ff; Bergman 2011a: 242). Hur man ska tolka att Femme Fatale-figuren Camilla Salander endast framställs som ett hot och som en samhällsomstörtande kraft, kan man givetvis diskutera. Personligen upplever jag att framställningen av Camilla Salander (men också av Lisbeth Salander) synliggör ett direkt och indirekt upprätthållande av en mängd patriarkala maktdiskurser, till exempel i relation till "faran” med kvinnlig emancipation. Man kan också ställa sig frågan varför avsändaren har valt att reproducera patriarkala föreställningar kopplade till att kvinnor, eller som i detta fall tvillingsystrar, endast ser varandra som motståndare och rivaler.

För att återkoppla till kärleksmotivet i trilogin har detta i den fjärde romanen i stort försvunnit. Istället kan Mikael Blomkvist i Det som inte dödar oss tolkas som en klassisk hjälpare i subjektets (Lisbeth Salander) kamp mot objektet (Camilla Salander). Nämnas bör också att de explicita intertexterna till pojkdetektiven Kalle Blomkvist inte alls används lika ymnigt som i trilogin. En annan avgörande förändring i den fjärde romanen är att de öppna och dolda intertexterna till Tomboy-figuren och Pippi-figuren minskat avsevärt. ${ }^{3}$ Som exempel kan man nämna att Lisbeth Salander i den fjärde romanen endast vid ett tillfälle liknas vid en Tomboy-gestalt, och då tvekar betraktaren om huvudkaraktären verkligen kan beskrivas som en androgyn pojkflicka (Lagercrantz 2015: 147). Beträffande den öppna och dolda dialogen med Pippi-figuren har även denna tonats ner rejält och även om Lisbeth Salander likt Pippi fortfarande är ekonomiskt oberoende, är detta ingenting som framhålls i Det som inte dödar oss. Inte heller betonas huvudkaraktärens sociala status i förhållande till sina föräldrar, utan istället ligger fokus på den konfliktfyllda relationen mellan tvillingsystrarna. Rörande de andra framträdande Pippi-elementen i trilogin, till exempel Lisbeth Salanders vemodiga och utomsociala drag, hennes skeva identitetsgörande och hennes Pippi-liknande kläd- och sminkmarkörer, har även dessa minskat avsevärt. Som tidigare påtalats identifieras Lisbeth Salander i den fjärde romanen överlag som en begriplig kvinna med en stabil kvinnokropp. Huvudkaraktärens skeva identitetsgörande har således nedtonats. Inte heller är Lisbeth Salander vemodig, utan snarare är hon konstant arg. Hennes makeup är uteslutande svart, och hennes kläder beskrivs alltid som endast svarta och punkiga. Detta mönster kan i sin tur tolkas som en fortsättning på den smink- och klädtransformation från Pippi Långstrump till superhjälte som enligt Philippa Gates (2013) påbörjas redan i

\footnotetext{
${ }^{3}$ Denna minskning av explicita och implicita intertexter till Tomboy-figuren och Pippi-figuren speglas även i Mannen som sökte sin skugga.
} 
Hollywoodfilmen The Girl with the Dragon Tattoo (2011) (Gates 2013: 209-211). De färgglada och brokiga knästrumporna, den färgrika makeupen och de korta, trasiga och skeva kjolarna från trilogin har således försvunnit i den fjärde romanen (Larsson 2005: 50). Visserligen kan Lisbeth Salander i den fjärde romanen fortfarande tolkas sakna social kompetens. Emellertid kan man ställa sig frågan om inte huvudkaraktärens ovilja till att anpassa sig efter vad andra människor tycker och tänker, snarare speglar en hårdkokt hjälte än en Pippi-figur då den hårdkokte hjälten kännetecknas av att vara just en självständig, individualistisk ensamvarg som inte bryr sig om sociala konventioner (Kärrholm 2011b: 91). Vidare förstärks detta intryck av att Lisbeth Salander inte litar på andra människor, inte har någon tilltro till samhället och att hon ständigt tar lagen i egna händer, ett annat utmärkande drag hos den hårdkokte hjälten (Kärrholm 2011b: 91).

Vad det gäller de explicita intertexterna till Pippi-figuren liknas Lisbeth Salander endast vid ett tillfälle vid Pippi (Lagercrantz 2015: 48). Nämnas bör dock att denna intertext lätt går förlorad eftersom de öppna intertextuella referenserna till Wasp-karaktären i den fjärde romanen dominerar och är centrala både i förhållande till intrigen och i förhållande till den direkta och indirekta karakteriseringen av Lisbeth Salander: "Men första gången jag såg en bild på Wasp hajade jag till. Det var väldigt mycket Lisbeth över henne” (Lagercrantz 2015: 373). Inte bara har de intertextuella referenserna till Wasp-gestalten ökat enormt och är centrala i berättelsen, utan de andra karaktärerna refererar ofta till Lisbeth Salander genom att kalla henne sitt alias, nämligen Wasp. Varför David Lagercrantz direkt och indirekt har valt att framhålla, förtydliga och förstärka likheterna mellan Lisbeth Salander och superhjälten Wasp är naturligtvis en tolkningsfråga, men man kan till exempel anta att Wasp-figuren tydliggör kampen mellan tvillingsystrarna då Camilla Salander liknas med Wasp-gestaltens antagonist, nämligen ärkeskurken Thanos. ${ }^{4}$ Man kan också anta att intertexterna till den mycket populära, men stereotypiska, superhjälten i det fiktiva Marvel-universumet är en medveten ideologisk och estetisk värde- och normanpassning för att Lisbeth Salander ska vara mer internationellt gångbar (Petersson 2011: 28). Utöver detta kan man anta att intertexterna är ett sätt för att leda och styra mottagarna i en helt annan riktning än i de litterära förlagorna, i kombination med att man vill återkoppla till huvudkaraktärens superhjältedrag i trilogin. Problematiken kring detta är bara att Lisbeth Salanders superhjältedrag från trilogin, till exempel hennes stora hackerkunskaper, idag inte är lika unika. Likaså framställs inte Lisbeth Salander i den fjärde romanen som en kvinnlig superintelligent "nörd” som ägnar sig åt hackning för att rädda världen, utan snarare framställs hon som en hårdkokt crackare som ägnar sig åt dataintrång främst för sin egen vinnings skull. Hur man än tolkar intertexterna till Wasp-karaktären bidrar de, i kombination med att intertexterna till Tomboy-figuren och Pippi-figuren överlag gått förlorade, till att man som läsare får en mer ensidig och stereotypisk bild av huvudkaraktären. Sammanfattningsvis kan man alltså säga att Lisbeth Salanders transformation från trilogin till den fjärde romanen,

\footnotetext{
${ }^{4}$ Thanos är en utomjordisk manlig ärkeskurk skapad av Mike Friedrich och Jim Starlin för det amerikanska serieförlaget Marvel Comics. Thanos namn alluderar på Thanatos, dödsguden i grekisk mytologi. Thanos superkrafter är att han mentalt kan flytta och transformera objekt (telekinesi). Han kan också läsa andras tankar, manipulera materia och utnyttja kosmisk energi. Utöver detta är Thanos superintelligent och har en övermänsklig yttre och inre styrka. Precis som Wasp har Thanos vid ett flertal gånger adapterats till TV och film. Som exempel kan man nämna att ärkeskurken skildras i filmerna Guardians of the Galaxy (2014) och Avengers: Age of Ultron (2015).
} 
kan beskrivas som en förskjutning från en komplex romanfigur som öppnar upp för olika tolkningar och flera tolkningsnivåer, till en stereotypisk hårdkokt hjälte som i stort tycks ha två framträdande egenskaper, nämligen argsinthet och våldsamhet.

\section{Avslutning}

Vad kan man då dra för slutsatser av Lisbeth Salanders transformation i Det som inte dödar oss? Utifrån analysen ovan kan Lisbeth Salanders transformation i den fjärde romanen kopplas till flera faktorer. För det första kan Lisbeth Salanders transformation ses som en direkt och indirekt genreanpassning eftersom den fjärde romanen, till skillnad från Millennium-trilogin, kan ses som en hårdkokt detektivroman med inslag från politisk thriller. Genom att David Lagercrantz tydligare har valt att skriva in sig i en viss genretradition, en på många sätt patriarkal genretradition, blir karaktärsbeskrivningen av Lisbeth Salander mer snäv och endimensionell. Den hårdkokte hjälten har helt enkelt inte så många personlighetsdrag och egenskaper. För det andra kan Lisbeth Salanders förändring ses som ett uttryck för att anpassa texten för en internationell marknad. Man kan till exempel anta att en Wasp-liknande kvinnlig hårdkokt hjälte med ett manligt kodat aktörskap av avsändare, förlag och marknaden överlag, förutsätts vara mer internationellt gångbar. Samtidigt kan man ställa sig frågan om det inte kan ses som problematiskt att utgå ifrån att en internationell målgrupp inte kan uppskatta en komplex och dynamisk kvinnlig detektivgestalt. Likaså kan man ställa sig frågan om Lisbeth Salanders transformation verkligen speglar den förväntade målgruppens estetiska och ideologiska normer och värderingar, eller om det snarare är så att huvudkaraktärens transformation speglar avsändarens, förlagets och marknadens normer och värderingar. För det tredje kan Lisbeth Salanders transformation ses som ett medvetet och omedvetet uttryck för att förstärka, upprätthålla och reproducera diverse patriarkala maktdiskurser. Ett upprätthållande av patriarkala värde- och makthierarkier som inte bara påverkar dialogen mellan text och mottagare, utan som också gör att Lisbeth Salander fortsätter samtalet över konstruerade medie-, språk-, kultur- och nationsgränser som en stereotypisk hårdkokt manlig hjälte, men i en stabil kvinnokropp.

\section{Referenser}

Bergman, Kerstin (2014), "From literary girl to graphic novel hero: trans-medial transformation of Stieg Larsson's Lisbeth Salander", The Journal of Specialised Translation 22: 93-109, Tillgänglig från: http://www.jostrans.org/issue22/art bergman.pdf [2017-05-02]

Bergman, Kerstin (2013a), "From "The Case of the Pressed Flowers" to the Serial Killer's Torture Chamber: The Use and Function of Crime Fiction Subgenres in Stieg Larsson's The Girl with the Dragon Tattoo", Rebecca Martin (red.), Critical Insights: Crime and Detective Fiction. Ipswich: Salem Press, s. 38-54.

Bergman, Kerstin (2013b), "Genre-Hybridization - a Key to Hyper-Bestsellers? The use and function of different fiction genres in The Da Vinci Code and The Millennium Trilogy”, Akademisk kvarter: Academic quarter 7: 106-118. Tillgänglig från: http://www.akademiskkvarter.hum.aau.dk/pdf/vol7/7a_KerstinBergman_GenreHybridi zation.pdf [2017-04-30] 
Bergman, Kerstin och Sara Kärrholm (2011), ”Inledning”, i Kerstin Bergman och Sara Kärrholm, Kriminallitteratur. Utveckling, genrer, perspektiv. Lund: Studentlitteratur, s. 9-12.

Bergman, Kerstin (2011a), ”Deckare och andra medier”, i Kerstin Bergman och Sara Kärrholm, Kriminallitteratur. Utveckling, genrer, perspektiv. Lund: Studentlitteratur, s. 220-262.

Bergman, Kerstin (2011b), "Thrillern”, i Kerstin Bergman och Sara Kärrholm, Kriminallitteratur. Utveckling, genrer, perspektiv. Lund: Studentlitteratur, s. 124-142.

Brigley Thompson, Zoë (2013), ”Male Fantasy, Sexual Exploitation, and the Femme Fatale: Reframing Scripts of Power and Gender in Neo-noir Novels by Sara Paretsky, Megan Abbott and Stieg Larsson”, i Berit Åström, Katarina Gregersdotter och Tanya Horeck (red.), Rape in Stieg Larsson's Millennium Trilogy and Beyond. London: Palgrave Macmillan, s. 136-153.

Bränström Öhman, Annelie (2013), "Salanders teorem: Lisbeth Salander som Millenniumtrilogins gåta”, i Siv Fahlgren, Anders Johansson och Eva Söderberg (red.), Millennium. Åtta genusvetenskapliga läsningar av den svenska välfärdsstaten genom Stieg Larssons Millennium-trilogi. Sundsvall: Mittuniversitetet, s. 67-84.

Butler, Judith (2007), Gender Trouble. Feminism and the Subversion of Identity. New York and London: Routledge Classics.

Collins, Jim (2010), Bring on the Books for Everybody. How Literary Culture Became Popular Culture. Durham och London: Duke University Press.

Fahlgren, Siv (2013), "Lisbeth Salander - feministiskt svar eller provokativ fråga?”, i Siv Fahlgren, Anders Johansson och Eva Söderberg (red.), Millennium. Åtta genusvetenskapliga läsningar av den svenska välfärdsstaten genom Stieg Larssons Millennium-trilogi. Sundsvall: Mittuniversitetet, s. 85-94.

Fincher, David (2011), The Girl with the Dragon Tattoo. Culver City: Columbia Pictures.

Gates, Philippa (2013), ''Hidden in the Snow': Female Violence against the Men Who Hate Women in the Millennium Adaptations”, Berit Åström, Katarina Gregersdotter och Tanya Horeck (red.), Rape in Stieg Larsson's Millennium Trilogy and Beyond. London: Palgrave Macmillan, s. 193-213.

Gunn, James (2014), Guardians of the Galaxy. Burbank: Marvel Studios.

King, Donna och Carrie Lee Smith (red.) (2012), Men Who Hate Women and Women Who Kick Their Asses. Stieg Larsson's Millennium Trilogy in Feminist Perspective. Nashville: Vanderbilt University Press.

Kärrholm, Sara (2011a), ”Deckare och genus”, i Kerstin Bergman och Sara Kärrholm, Kriminallitteratur. Utveckling, genrer, perspektiv. Lund: Studentlitteratur, s. 186-202.

Kärrholm, Sara (2011b), ”Den hårdkokta deckaren”, i Kerstin Bergman och Sara Kärrholm, Kriminallitteratur. Utveckling, genrer, perspektiv. Lund: Studentlitteratur, s. 88-104.

Kärrholm, Sara (2011c), ”Detektivgestalten”, i Kerstin Bergman och Sara Kärrholm, Kriminallitteratur. Utveckling, genrer, perspektiv. Lund: Studentlitteratur, s. 54-67.

Lagercrantz, David (2017), Mannen som sökte sin skugga. Stockholm: Norstedts Förlag.

Lagercrantz, David (2015), Det som inte dödar oss. Stockholm: Norstedts Förlag.

Larsson, Stieg (2007), Luftslottet som sprängdes. Stockholm: Norstedts Förlag.

Larsson, Stieg (2006), Flickan som lekte med elden. Stockholm: Norstedts Förlag.

Larsson, Stieg (2005), Män som hatar kvinnor. Stockholm: Norstedts Förlag.

Lindgren, Astrid (1948) [1989], Pippi Långstrump i Söderhavet. Stockholm: Rabén \& Sjögren.

Lindgren, Astrid (1946) [1995], Pippi Långstrump går ombord. Stockholm: Rabén \& Sjögren.

Lindgren, Astrid (1945) [2005], Pippi Långstrump. Stockholm: Rabén \& Sjögren. 
Lundqvist, Ulla (1994) Tradition och förnyelse. Svensk ungdomsbok från sextiotal till nittiotal. Stockholm: Rabén \& Sjögren.

Ohlsson, Anders (2002), "Den filmiserade romanen”, i Hans Lund (red.), Intermedialitet. Ord, bild och ton i samspel. Lund: Studentlitteratur, 2002, s. 235-241.

Petersson, Margareta (2011), "Översättning”, i Margareta Petersson (red.), Världens litteraturer. En gränsöverskridande historia. Lund: Studentlitteratur, s. 28-32.

Reed, Peyton (2018), Ant-Man and the Wasp. Burbank: Marvel Studios.

Scaggs, John (2005), Crime Fiction. London och New York: Routledge.

Svedjedal, Johan (2015), ”Nya Millennium är skicklig och respektfull”, Dagens Nyheter,. Tillgänglig från: http://www.dn.se/dnbok/bokrecensioner/nya-millennium-ar-skickligoch-respektfull/?forceScript=1\&variantType=large [2017-05-13].

Söderberg, Eva (2013), ”'Lillasyster ser dig!” Om Pippi Långstrump, Lisbeth Salander och andra Pippi-gestalter”, i Siv Fahlgren, Anders Johansson och Eva Söderberg (red.), Millennium. Åtta genusvetenskapliga läsningar av den svenska välfärdsstaten genom Stieg Larssons Millennium-trilogi. Sundsvall: Mittuniversitetet, s. 51-66.

Whedon, Joss (2015), The Avengers: Age of Ultron. Burbank: Marvel Studios.

Öhman, Anders (2006), Populärlitteratur. De populära genrernas estetik och historia. Lund: Studentlitteratur. 